\title{
PEMANFAATAN UDANG KERING (EBI) DALAM PEMBUATAN NUGGET TEMPE
}

\author{
Dian Kurnia Rahayu, Esthy Rahman Asih, Yuliana Arsil \\ Jurusan Gizi Politeknik Kesehatan Kemenkes Riau
}

\begin{abstract}
ABSTRAK
Data BPS Riau menunjukkan bahwa produksi udang krosok yang merupakan salah satu jenis udang yang paling banyak digunakan untuk pembuatan udang kering (ebi) berjumlah 39 ton pada tahun 2015. Udang kering (ebi) dapat digunakan sebagai bahan tambahan dalam pembuatan produk tertentu, salah satunya adalah nugget. Pemanfaatan udang kering (ebi) dalam pembuatan nugget tempe ini diharapkan mampu untuk meminimalisir rasa tempe yang kurang disukai serta aroma langu yang diperoleh dari tempe yang digunakan sebagai bahan baku utama dalam pembuatan nugget.

Jenis penelitian ini adalah eksperimental dengan desain penelitian Rancangan Acak Lengkap (RAL) dimana perbedaan persentase udang kering (ebi) dan persentase tempe yang digunakan terdiri dari 4 perlakuan yaitu 2,5\%:97,5\%; $5 \%: 95 \% ; 7,5 \%: 92,5 \%$ dan kontrol (tanpa ebi). Nugget tempe yang dihasilkan diuji organoleptik oleh 25 orang panelis semi terlatih. Data yang diperoleh dianalisis statistik dengan menggunakan uji ANOVA tingkat kepercayaan $99 \%(\alpha=0,01)$ dan apabila ada perbedaan nyata akan dilakukan uji lanjut DMRT (Duncan's Multiple Range Test)

Berdasarkan hasil uji organoleptikterdapat pengaruh pemanfaatan udang kering (ebi) terhadap rasa dan aroma nugget tempe, tetapi tidak berpengaruh terhadap warna dan tekstur nugget tempe. Perlakuan substitusi udang kering (ebi) sebanyak 7,5\% menjadi perlakuan yang paling disukai oleh panelis dari segi rasa, aroma, warna dan tekstur, dimana rata-rata tingkat kesukaan terhadap rasa 4,12; warna 3,80; aroma 4,0 dan tekstur 3,80 .
\end{abstract}

Kata Kunci :Nugget, tempe, udang kering (ebi), uji organoleptik

\section{PENDAHULUAN Latar Belakang}

Saat ini pola konsumsi masyarakat yang kebarat-baratan (western style diet) atau yang dikenal sebagai "makanan siap saji" dan "makanan jadi" semakin popular. Makanan siap santap ini sudah banyak terdapat di pasaran seperti sosis, bakso dan nugget. Nugget dikenal sebagai makanan siap saji yang dapat diterima oleh masyarakat terutama anak-anak yang identik dengan makanan yang cepat dikonsumsi dan mudah didapatkan (Sumantri dkk, 2015).

Produk nugget yang ada di pasaran biasanya berupa nugget ayam, nugget daging sapi dan nugget ikan. Saat ini nugget ayam adalah salah satu produk pangan yang paling banyak ditemukan di pasaran (Bintoro, 2008).Nugget ayam disukai karena memiliki rasa yang lezat, tetapi mengandung komposisi lemak yang tinggi yaitu 18,82 g/100 g dan kandungan seratnya yang rendah yaitu $0,9 \mathrm{~g} / 100$ g(Alfiana, 2014).

Kandungan lemak yang tinggi pada ayam dapat diganti dengan sumber bahan pangan lokal yaitu tempe yang memiliki kandungan protein tinggi namun lemaknya rendah. Menurut Adianingsih (2012), tempe merupakan salah satu nabati yang mengandung protein $(20,8 \mathrm{~g} / 100 \mathrm{~g}$ bahan) 
lebih tinggi dari protein daging ayam (18,2 $\mathrm{g} / 100 \mathrm{~g}$ bahan). Tempe merupakan sumber protein, serat pangan, kalsium, vitamin B dan zat besi (Permatasari, 2012).

Tempe masih memiliki kendala dalam penyimpanan dan pemanfaatannya yaitu umur simpan yang relatif singkat dan mudah rusak. Agar khasiat zat-zat yang bermanfaat tidak banyak terbuang, tempe sebaiknya diolah menjadi produk pangan lain yang dapat diterima dan dikenal luas oleh masyarakat serta bersifat lebih komersil salah satunya nugget (Sumantri dkk, 2015).

Selain dari umur simpan yang relatif pendek serta mudah rusak, tempe juga memiliki kelemahan yaitu aroma langu yang kurang disukai. Oleh sebab itu, perlu dilakukannya penambahan bahan pangan lain untuk meminimalisir aroma langu dari tempe tersebut dalam pembuatan nugget. Bahan pangan yang dapat ditambahkan salah satunya adalah udang kering (ebi).

Udang merupakan salah satu bahan pangan dengan kandungan protein yang tinggi yang sangat bermanfaat bagi kesehatan terutama bagi pertumbuhan anak. Kandungan vitamin baik jenis vitamin larut air dan vitamin larut lemak juga sangat tinggi pada udang sehingga sangat baik untuk dikonsumsi. Udang juga mengandung berbagai mineral yang penting bagi tubuh. (Rusmiyati, 2013).

Udang segar memiliki kelemahan antara lain adalah masa simpan yang relatif singkat, harga yang mahal serta berat dapat dimakan (BDD) yang sedikit yaitu sebesar 68\% (DKBM, 2017). Oleh sebab itu, udang kering (ebi) merupakan salah satu alternatif bahan pangan yang dapat digunakan untuk menggantikan udang segar karena udang kering (ebi) memiliki berat dapat dimakan BBD yang cukup besar yaitu sebesar 90\% (DKBM, 2017). Selain itu, kandungan protein udang kering (ebi) juga tinggi yaitu sebesar 62 $\mathrm{g} / 100 \mathrm{~g}$ bahan (TKPI, 2017).

Ebi merupakan hasil olahan dari udang segar yang diolah menjadi udang kering dan biasanya dapat diolah lebih lanjut menjadi bumbu masak.Penggunaan ebi pada berbagai menu masakan adalah untuk memperoleh aroma udang dan sebagai penyedap rasa masakan (Bank Indonesia, 2008).

Data BPS (Badan Pusat Statistik) Riau tahun 2015 menunjukkan bahwa produksi udang krosok yang merupakan salah satu jenis udang yang paling banyak digunakan untuk pembuatan udang kering (ebi) berjumlah 39 ton. Beberapa daerah di Riau seperti Kabupaten Indragiri Hulu dan Indragiri Hilir dikenal sebagai penghasil udang kering (ebi).

Udang kering (ebi) dapat digunakan sebagai bahan tambahan dalam pembuatan produk tertentu, salah satunya adalah nugget. Pemanfaatan udang kering (ebi) dalam pembuatan nugget tempe ini diharapkan mampu untuk meminimalisir rasa tempe yang kurang disukai serta aroma langu yang diperoleh dari tempe yang digunakan sebagai bahan baku utama dalam pembuatan nugget.

Berdasarkan hal tersebut diatas, maka sangat potensial dilakukan penelitian mengenai penggunaan tempe dan udang kering dalam pembuatan nugget sebagai alternatif produk nugget. Oleh sebab itu, maka dilakukan penelitian dengan judul "Pemanfaatan Udang Kering (Ebi) dalam Pembuatan Nugget Tempe". Identifikasi Masalah

Berdasarkan latar belakang di atas maka permasalahan dalam penelitian ini adalah bagaimana pengaruh pemanfaatan udang kering (ebi) dalam pembuatan nugget tempe terhadap sifat organoleptik nugget.

\section{Tujuan Penelitian}

1. Mengetahui pengaruh pemanfaatan udang kering (ebi) terhadap rasa nugget tempe.

2. Mengetahui pengaruh pemanfaatan udang kering (ebi) terhadap terhadap warna nugget tempe.

3. Mengetahui pengaruh pemanfaatan udang kering (ebi) terhadap aroma nugget tempe. 
4. Mengetahui pengaruh pemanfaatan udang kering (ebi) terhadap tekstur nugget tempe.

\section{METODE PENELITIAN}

\section{Alat dan Bahan}

Alat-alat yang digunakan adalah timbangan, pisau, blender, baskom, sendok, talenan, loyang petak, kompor, dandang, kuali, sendok penggoreng, saringan alumnium dan piring.

Bahan-bahan yang digunakan adalah tempe yang dibungkus dengan daun, udang kering (ebi), roti tawar yang telah dikupas kulit luarnya, susu skim, tepung roti, telur, bawang merah, bawang putih, merica, air es, garam, gula dan minyak goreng.

\section{Rancangan Penelitian}

Jenis penelitian ini adalah eksperimental dengan desain penelitian Rancangan Acak Lengkap (RAL) dimana perlakuan perbedaan persentase udang kering (ebi) dan persentase tempe yang digunakan terdiri dari 4 perlakuan yaitu 2,5\%: $97,5 \%$ (perlakuan A), 5\%: $95 \%$ (perlakuan B) dan 7,5\% : 92,5\% (perlakuan C)dan perlakuan D adalah nugget tempe kontrol (tanpa penambahan ebi). Penelitian ini terdiri dari 2 tahap yaitu penelitian pendahuluan dan penelitian lanjutan.

Pada proses pembuatan nugget digunakan 4 kelompok perlakuan yang disajikan pada Tabel 1 .

\section{Tabel 1}

Penggunaan bahan pada setiap perlakuan

\begin{tabular}{lcccc}
\hline \multirow{2}{*}{ Bahan } & \multicolumn{4}{c}{ Perlakuan } \\
\cline { 2 - 5 } & $\mathrm{A}$ & $\mathrm{B}$ & $\mathrm{C}$ & $\mathrm{D}$ \\
\hline Ebi & $10 \mathrm{~g}$ & $20 \mathrm{~g}$ & $30 \mathrm{~g}$ & $0 \mathrm{~g}$ \\
Tempe & $390 \mathrm{~g}$ & $380 \mathrm{~g}$ & $370 \mathrm{~g}$ & $400 \mathrm{~g}$ \\
Roti & $4 \mathrm{lbr}$ & $4 \mathrm{lbr}$ & $4 \mathrm{lbr}$ & $4 \mathrm{lbr}$ \\
tawar & & & & \\
$\begin{array}{l}\text { Susu } \\
\text { skim }\end{array}$ & $40 \mathrm{~g}$ & $40 \mathrm{~g}$ & $40 \mathrm{~g}$ & $40 \mathrm{~g}$ \\
Telur & $1 \mathrm{btr}$ & $1 \mathrm{btr}$ & $1 \mathrm{btr}$ & $1 \mathrm{btr}$ \\
Gula & $3 \mathrm{~g}$ & $3 \mathrm{~g}$ & $3 \mathrm{~g}$ & $3 \mathrm{~g}$ \\
\hline
\end{tabular}

\begin{tabular}{|c|c|c|c|c|}
\hline $\begin{array}{l}\text { pasir } \\
\text { Garam }\end{array}$ & $6 \mathrm{~g}$ & $6 \mathrm{~g}$ & $6 \mathrm{~g}$ & $6 \mathrm{~g}$ \\
\hline $\begin{array}{l}\text { Bawang } \\
\text { merah }\end{array}$ & $5 \mathrm{~g}$ & $5 \mathrm{~g}$ & $5 \mathrm{~g}$ & $5 \mathrm{~g}$ \\
\hline $\begin{array}{l}\text { Bawang } \\
\text { putih }\end{array}$ & $7 \mathrm{~g}$ & $7 \mathrm{~g}$ & $7 \mathrm{~g}$ & $7 \mathrm{~g}$ \\
\hline Merica & $5 \mathrm{~g}$ & $5 \mathrm{~g}$ & $5 \mathrm{~g}$ & $5 \mathrm{~g}$ \\
\hline $\begin{array}{l}\text { Air es } \\
\text { Bahan } \\
\text { pelapis }\end{array}$ & $10 \mathrm{~g}$ & $10 \mathrm{~g}$ & $10 \mathrm{~g}$ & $10 \mathrm{~g}$ \\
\hline $\begin{array}{l}\text { Putih } \\
\text { telur }\end{array}$ & $2 \mathrm{btr}$ & $2 \mathrm{btr}$ & $2 \mathrm{btr}$ & $2 \mathrm{btr}$ \\
\hline $\begin{array}{l}\text { Tepung } \\
\text { roti }\end{array}$ & $30 \mathrm{~g}$ & $30 \mathrm{~g}$ & $30 \mathrm{~g}$ & $30 \mathrm{~g}$ \\
\hline
\end{tabular}

Prosedur kerja pembuatan nugget tempe dapat dilihat pada Gambar 1.
Udang kering (ebi) direndam dengan air hangat lalu ditiriska dan diblender *

Tempe dipotong dan dikukus selama 30 menit pada suhu $95^{\circ} \mathrm{C}$ lalu didinginkan dan diblender *

Udang kering (ebi) dan tempe dicampur menjadi satu adonan *

Roti tawar direndam dalam susu skim cair hingga lembut

Ditambahkan bumbu lain, telur dan roti tawar yang telah direndam susu skimlalu diaduk menjadi satu adonan

Adonan dicetak dalam loyang yang telah dilapisi minyak goreng lalu dikukus selama 45 menit pada suhu $95^{\circ} \mathrm{C} *$ Adonan diangkat dan didinginkan lalu dipotong-potong

Potongan nugget dicelupkan ke dalam putih telur kemudian digulingkan pada tepung panir lalu dimasukkan ke dalam freezer dengan suhu $3^{\circ} \mathrm{C}$ selama 6 jam Nugget yang telah dibekukan kemudian digoreng dalam minyak panas dengan suhu $120^{\circ} \mathrm{C}$ selama 3 menit $*$ 


\section{Gambar 1. Alur Pembuatan Nugget Tempe}

Sumber : (Permatasari, 2012 yang telah dimodifikasi)

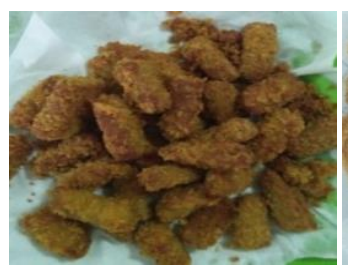

Gambar 1.

A. $(2,5 \%: 97,5 \%)$

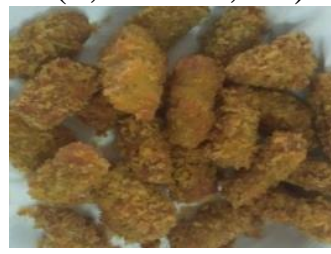

Gambar 3.

C. $(2,5 \%: 97,5 \%)$ D. (kontrol)

\section{Uji Organoleptik}

Berdasarkan hasil pengujian organoleptik terhadap empat perlakuan yang berbeda yang meliputi rasa, warna, aroma dan tekstur nugget tempe dengan pemanfaatan udang kering (ebi) diperoleh hasil menggunakan Uji Duncan yang dapat dilihat pada Tabel 2.

Tabel 2. Hasil Uji

OrganoleptikTerhadap Rasa, Warna, Aroma dan TeksturNugget Tempe

\begin{tabular}{|c|c|c|c|}
\hline \multirow{2}{*}{ Perlakuan } & \multicolumn{3}{|c|}{ Parameter } \\
\hline & Rasa & Warna & Aroma \\
\hline $\begin{array}{l}\text { A }(2,5 \%: \\
97,5 \%)\end{array}$ & $3,36^{\mathrm{ab}}$ & $3,60^{\mathrm{a}}$ & $3,64^{\mathrm{ab}}$ \\
\hline $\begin{array}{l}\text { B (5\%: } \\
95 \%)\end{array}$ & $3,68^{\mathrm{bc}}$ & $3,80^{\mathrm{a}}$ & $3,96^{\mathrm{b}}$ \\
\hline $\begin{array}{l}C(7,5 \%: \\
92,5 \%)\end{array}$ & $4,12^{c}$ & $3,80^{\mathrm{a}}$ & $4,0^{\mathrm{b}}$ \\
\hline $\begin{array}{l}\mathrm{D}(100 \% \\
\text { kontrol) }\end{array}$ & $3,04^{\mathrm{a}}$ & $3,48^{\mathrm{a}}$ & $3,4^{\mathrm{a}}$ \\
\hline
\end{tabular}

Ket : Angka-angka yang diikuti oleh huruf kecil yang berbeda pada kolom yang sama menunjukkan perbedaan nyata $(\mathrm{P}<0,01)$.

Rasa
Berdasarkan hasil uji ANOVA, diperoleh hasil $p$ hitung dari rasa nugget tempe adalah $p=0,000(p<0,01)$. Hal ini menunjukkan bahwa ada pengaruh yang nyata dari pemanfaatan udang kering (ebi) terhadap rasa nugget tempe, maka dapat disimpulkan bahwa ada perbedaan rasa dari perbedaan perlakuan nugget tempe. Hal ini disebabkan karena penambahan udang kering (ebi) dalam pembuatan nugget tempe dapat menutupi rasa khas tempe yang kurang disukai.Penambahan bahan pangan lain seperti udang kering (ebi) dapat menambah rasa gurih dari produk yang dihasilkan.

Sebagaimana diketahui rasa gurih pada udang kering (ebi) berasal dari kandungan asam glutamat. Kandungan asam glutamat pada udang kering (ebi) berjumlah 2,7 gram/100 gram bahan. Subagio (2006)menyatakanbahwa rasa gurih didapatkan dari senyawa asam-asam amino, seperti asam glutamat. Sedangkan Amaliafitri (2010)dalam Karim (2014) menyatakanbahwa asam glutamat merupakan sumber rasa umami (gurih) paling dominan dan berdampakpada kesempurnaan atau keaslian dari rasa itu sendiri.

Hasil yang diperoleh menunjukkan bahwa semakin banyak penambahan udang kering (ebi) maka semakin tinggi rata-rata tingkat kesukaan panelis terhadap rasa nugget tempe yang dihasilkan.Penelitian yang dilakukan oleh Permatasari (2012) menunjukkan bahwa terjadi peningkatan tingkat kesukaan panelis terhadap rasa

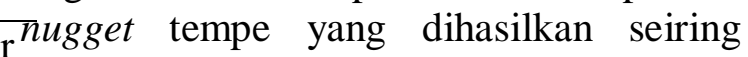
dengan peningkatan jumlah ikan mujair yang ditambahkan dalam pembuatan nugget tempe.

$3,84^{\mathrm{a}}$

\section{Warna}

3,80 a Berdasarkan hasil uji ANOVA, diperoleh hasil $p$ hitung dari warna nugget $3,68^{\mathrm{a}}$ tempe adalah $p=0,384(p>0,01)$. Hal ini menunjukkan bahwa tidak ada pengaruh yang nyata dari pemanfaatan udang kering (ebi) terhadap warna nugget tempe, maka dapat disimpulkan bahwa tidak ada 
perbedaan warna dari keempat kelompok perlakuan nugget tempe. Hal ini disebabkan karena penambahan udang kering (ebi) dalam pembuatan nugget tempe tidak mempengaruhi warna nugget yang dihasilkan. Warna udang kering (ebi) yang orange tidak mempengaruhi warna nugget tempe yang dihasilkan.

Warna nugget tempe yang dihasilkan adalah cokelat. Permukaan nugget tempe yang berwarna cokelat dapat terjadi karena proses penggorengan yang mengakibatkan terjadinya reaksi Maillard yaitu reaksi pencoklatan non enzimatis karena adanya reaksi antara gula pereduksi dengan gugus amin bebas dari asam amino atau protein. Warna cokelat merupakan akhir dari reaksi aldehid yang aktif terpolimerisasi dengan gugus amino membetuk senyawa cokelat yang disebut melanoidin (Muchtadi, 2010).

Tingkat intensitas warna yang ditimbulkan dipengaruhi oleh lama penggorengan, suhu dan komposisi kimia pada permukaan luar bahan dari pangan (Leo dan Nollet, 2007).

\section{Aroma}

Berdasarkan hasil uji ANOVAdiperoleh hasil $p$ hitung dari aroma nugget tempe adalah $p=0,008$ $(p<0,01)$. Hal ini menunjukkan bahwa ada pengaruh yang nyata dari pemanfaatanudang kering (ebi) terhadap aroma nugget tempe, maka dapat disimpulkan bahwa ada perbedaan aroma dari perbedaan perlakuan nugget tempe. Hal ini disebabkan karenapenambahan udang kering (ebi) dalam pembuatan nugget tempe dapat menutupi aroma tempe yang langu.

Tempe merupakan salah satu produk fermentasi kedelai yang memiliki senyawa penyebab off flavor (penyimpangan cita rasa dan aroma pada produk olahan kedelai) yang berasal dari kedelai. Salah satu penyimpangan aromanya adalah bau langu. Bau langu ditimbulkan oleh kerja enzim lipoksinase yang ada dalam biji kedelai. Enzim tersebut bereaksi dengan lemak dan menghasilkan suatu senyawa organik yaitu etil-fenil-keton (Esvandiari dkk, 2010).

Hasil yang diperoleh menunjukkan bahwa semakin banyak penambahan udang kering (ebi) maka semakin tinggi rata-rata tingkat kesukaan panelis terhadap aroma nugget tempe yang dihasilkan. Hal ini sejalan dengan penelitian Permatasari (2012) yang menunjukkan bahwa terjadi peningkatan tingkat kesukaan panelis terhadap aroma nugget tempe seiring dengan peningkatan jumlah ikan mujair yang ditambahkan dalam pembuatan nugget tempe.

\section{Tekstur}

Berdasarkan hasil uji ANOVA, diperoleh hasil $p$ hitung dari teksturnugget tempe adalah $p=0,846(p>0,01)$. Hal ini menunjukkan bahwa tidak ada pengaruh yang nyata dari pemanfaatan udang kering (ebi) terhadap teksturnugget tempe, maka dapat disimpulkan bahwa tidak ada perbedaan tekstur dari keempat kelompok perlakuan nugget tempe. Hal ini disebabkan karena penambahan udang kering (ebi) dalam jumlah yang sedikit dalam pembuatan nugget tempe tidak mempengaruhi teksturnugget yang dihasilkan.

Tekstur pada nugget dipengaruhi oleh bahan pengisi, bahan pengikat dan bahan pelapis yang digunakan. Bahan pengisi yang digunakan dalam pembuatan nugget tempe adalah roti tawar. Menurut Amaliyah (2009)roti tawar berfungsi untuk membuat tekstur nugget menjadi kenyal. Selain itu, fungsi penambahan roti tawar dalam pembuatan nugget adalah untuk mengempukkan tekstur nugget agar tidak terlalu keras.

Bahan pengikat yang digunakan dalam pembuatan nugget tempe adalah telur dan susu skim. Menurut Anggorowati (2016), telur berfungsi sebagai emulsifier alami dalam pembuatan nugget. Telur juga berfungsi membentuk struktur dan kekokohan nugget. Sedangkan susu skim berguna sebagai bahan pengikat yang 
mampu membentuk tekstur produk dalam pengolahan pangan.

Bahan pelapis yang digunakan pada pembuatan nugget tempe adalah putih telur dan tepung roti. Menurut Owens (2001), faktor yang mempengaruhi tekstur nugget adalah tepung roti pada saat proses breading. Selain itu tekstur pada nugget tempe juga dipengaruhi oleh tekstur tempe itu sendiri. Menurut Kasmidjo (1990) tekstur tempe yang kompak disebabkan oleh miselia-miselia jamur yang menghubungkan antara biji-biji kedelai sebagai bahan utama pembuatan tempe.

\section{Kesimpulan}

Berdasarkan hasil penelitian yang telah dilakukan dapat disimpulkan sebagai berikut :

1. Ada pengaruh pemanfaatan udang kering (ebi) terhadap rasa nugget tempe yaitu semakin banyak jumlah pemanfaatan udang kering (ebi) maka semakin tinggi tingkat kesukaan panelis terhadap rasa nugget tempe.

2. Tidak ada pengaruh pemanfaatan udang kering (ebi) terhadap warna nugget tempe.

3. Ada pengaruh pemanfaatan udang kering (ebi) terhadap aroma nugget tempe yaitu semakin banyak jumlah pemanfaatan udang kering (ebi) maka semakin tinggi tingkat kesukaan panelis terhadap aroma nugget tempe.

4. Tidak ada pengaruh pemanfaatan udang kering (ebi) terhadap tekstur nugget tempe.

\section{Saran}

Sebaiknya untuk penelitian selanjutnya dapat dilakukan analisa proksimat terhadap masing-masing perlakuan nugget tempe yang dihasilkan.

\section{DAFTAR PUSTAKA}

Alfiana. 2014. Karakteristik Nugget Tempe dengan Variasi Penambahan Jamur Merang dan Tiram. Skripsi. Jember : Jurusan Teknologi Hasil
Pertanian, Fakultas Teknologi Pertanian. Universitas Jember.

Amaliyah, N. 2009. Perbedaan Kualitas Nugget Kacang Merah (Phaseoulus vulgaris) sebagai Alternatif Makanan untuk Vegetarian. Skripsi. Semarang : Jurusan Teknologi Jasa dan Produksi, Fakultas Teknik. Universitas Negeri Semarang.

Anggorowati, P.Y. 2016. Pengaruh Konsentrasi Tempe dan Konsentrasi Bahan Pengisi Terhadap Karalteristik Nugget Terubuk (Saccarum edule hasskarl). Skripsi. Bandung : Studi Teknologi Pangan, Fakultas Teknik. Universitas Pasundan.

Bank Indonesia. 2008. Pola Pembiayaan Usaha Kecil Pengolahan Ebi Kering.

Bintoro, V. P. 2008. Teknologi Pengolahan Daging dan Analisa Produk. Universitas Diponegoro, Semarang.

Daftar Komposisi Bahan Makanan (DKBM). 2017. Direktorat Gizi. Departemen Kesehatan RI.

Esvandiari, M., H. Sholihin dan A. Suryatna. 2010. Studi Kerja Adsorbsi Arang Aktif-Bentonit pada Aroma Susu Kedelai. Jurnal Sains dan Teknologi Kimia. Vol. 2 (1) : 135-149.

Karim, F. A., F. Swastawati dan A. D. Anggo. 2014. Pengaruh Perbedaan Bahan Baku Terhadap Kandungan Asam Glutamat pada Terasi. Jurnal Pengolahan dan Bioteknologi Hasil Perikanan. Vol. 3 (4) : 51-58.

Kasmidjo, R. B. 1990. Tempe : Mikrobiologi dan Kimia Pengolahan serta Pemanfaatannya. Yogyakarta : PAU Pangan dan Gizi UGM.

Leo, M. and L. Nollet. 2007. Handbook of Meat Poultry and seafood Quality. Blackwell Publishing John Wiley an Sons, Inc. New York.

Muchtadi, D. 2010. Teknik Evaluasi Nilai Gizi Protein. Bandung : Alfabeta. 
Owens, C. M. 2001. Poultry Meat Processing. CRC Press LCC. Department of Poultry Science., Texas.

Permatasari, P. K. 2012. Nugget Tempe dengan Substitusi Ikan Mujair Sebagai Alternatif Makanan Sumber Protein, Serat dan Rendah Lemak. Skripsi. Semarang :Program Studi Ilmu Gizi Fakultas Kedokteran. Universitas Diponegoro.

Rusmiyati, S. 2013. Menjala Rupiah Budidaya Udang Vannamei. Yogyakarta : Pustaka Baru Press.

Subagio, A. 2006. Mengembangkan Terasi Instan. Food Review IndonesiaVol. 1 No.9 Oktober 2006.

Sumantri, B., A. Ali dan V.S. Johan. 2015. Pemanfaatan Tempe dengan Jamur Tiram (Pleurotus ostreatus) dalam Pembuatan Nugget.Jurnal Jom Faperta, 2 (2).

Tabel Komposisi Pangan Indonesia (TKPI). 2017. Persatuan Ahli Gizi Indonesia. Jakarta : PT Elex Media Komputindo. 